\title{
In vitro Propagation of the Biodiesel Plant Jatropha curcas L.
}

\author{
K. Kalimuthu*, S. Paulsamy ${ }^{1}$, R. Senthilkumar and M. Sathya \\ Department of Biotechnology, Hindusthan College of Arts and Science, \\ Coimbatore-641 028, India
}

Key words: Jatropha curcas, Nodal explants, Cotyledons, Somatic Embryos, Multiple shoot formation

\begin{abstract}
The biodiesel plant, Jatropha curcas L. was micropropagated using nodal explants on MS supplemented with BAP $(1.5 \mathrm{mg} / \mathrm{l}), \mathrm{Kn}(0.5 \mathrm{mg} / \mathrm{l})$ and IAA $(0.1 \mathrm{mg} / \mathrm{l})$. Somatic embryos were induced directly from green cotyledon explants on MS fortified with $2 \mathrm{mg} / 1$ of BAP. The results of histological studies showed that several layers of meristematic cells participated in the formation of somatic embryos. Rooting was effectively achieved on MS supplemented with IAA at 1.0 $\mathrm{mg} / \mathrm{l}$. The subsequent hardening experiment showed that the commercial medium containing a mixture of decomposed coir waste, perlite and organic compost in the ratio of 1:1:1 by volume was most effective, $80 \%$ plantlets survived.
\end{abstract}

\section{Introduction}

Plant species with rich secondary metabolites have proved to be difficult for mass propagation through tissue culture (Roy 1995). In vitro techniques are being increasingly applied for clonal propagation of selected tree species to supplement conventional methods which have their limitations especially when a large number of genetically uniform propagules are required (Mascarenhas et al. 1981, Mascarenhas and Muralidharan 1989).

Jatropha curcas L. (Euphorbiaceae), a drought tolerant perennial plant species has received global attention due to its seed which contains 40 - $50 \%$ semi drying oil. It is used as an efficient substitute for diesel fuel (Takeda 1982, Banerji et al. 1985, Martin and Mayeux 1985, Muhlbauer et al. 1998). Realizing the importance of renewable energy sources, countries like Cape Verde, Madagascar, Nicaragua, Brazil, Mali etc. are using the seeds of J. curcas for large scale production of biodiesel (Heller 1996). The centre of origin of this species is known to be in

${ }^{*}$ Corresponding author: E-mail: k_kalimuthu@rediffmail.com ${ }^{1}$ Department of Botany, Kongunadu Arts \& Science College, Coimbatore-641 029, India. 
South America (Brazil); later it spread all tropical regions (Dehgan and Webster 1979). The oil yield from kernels is estimated between 46 and $58 \%$ derived from a semi-drying oil (iodine value 93 - 107) containing mainly oleic (37 - 63\%), linoleic $(19-40 \%)$ and palmitic $(12-17 \%)$ acids as constituents of fatty acids. Medicinally the oil is used as a purgative and emetic and against coetaneous disease (Godbole et al. 1966). It is also used for burning and spinning in the manufacture of hard soaps and candles, paints and lubricants (Roy 1990).

The seeds of J. curcas are of great commercial interest in the recent decade for their fuel value. To exploit the oil at a maximum extent, it is necessary to select the best genotype for oil contents and quality. The genetic diversity in the natural population appears narrow since no remarkable morphological differences have been observed (Sujatha and Mukta 1996). Studies with mutation breeding and interspecific crossing have made little progress in increasing variability in this species (Sakaguchi et al. 1987). A great number of new approaches to genetic manipulation relied on the use of cell or tissue culture (Larkin and Scowcroft 1981) and these techniques can be efficiently applied to plants like J. curcas where the genetic variability is limited. Unlimited potential exists in India, to convert the uncultivable and unproductive lands into green oil field of Jatropha, for its multiple uses. The drought résistance, non palatability, suitability to various climatic and soil conditions, faster rate of growth and perennial nature are the other preferable characters for the selection of the species J. curcas for cultivation (Roy 1998, Roy and Kumar 1990). The non-consumptive utilization of the plant will facilitate the protection of environment and ensure faster and durable greening of the country, help conserve soil and water and provide permanent renewable source of energy.

In order to meet the demand of fuel in the near future, the development of appropriate technology for the rapid regeneration of this species is essential. The conventional method of propagation through seeds will not solve the problem. Under this situation in vitro regeneration of this species through tissue culture techniques offers a powerful method to overcome the problem. A number of reports on the micropropagation of Jatropha podagrica (Spera et al. 1997) and J. integerrima (Sujatha and Prabakaran 2003, Sujatha and Dhingra (1993) are available. Protocols developed for micropropagation of Jatropha species by Sujatha and Mukta (1996), Sujatha and Probakaran (2003), Rojore and Batra (2005), Sujatha et al. (2005) were not promising because the multiplication rate was low. To meet the challenge the present investigation was launched, using different explants and $\mathrm{Kn}$ in various concentrations in an attempt to maximize micropropagation rate of $J$. curcas. The paper reports two efficient and reproducible methods for micropropagation of this species using nodal explants and green cotyledon explants for somatic embryogenesis. 


\section{Materials and Methods}

Seeds of J. curcas were collected from six - eight year-old plants growing in Classic Jatropha Oil India Limited, Palladam, Coimbatore, India. The seeds were washed with a mild detergent solution followed by another wash with $70 \%$ ethanol for $3 \mathrm{~min}$. before sterilizing the material with a $0.12 \%$ mercuric chloride solution for $10 \mathrm{~min}$. After washing thrice with sterile distilled water, the embryos were dissected out from the seeds and inoculated aseptically on MS containing $30 \mathrm{~g} / 1$ sucrose and $8 \mathrm{~g} / 1$ of agar (Table 3). The cultures were maintained at $24 \pm$ $2^{\circ} \mathrm{C}$ in total darkness for $24 \mathrm{~h}$ followed by their exposure to $14 \mathrm{~h}$ cool white florescent light $\left(30 \mu \mathrm{mol} \mathrm{m} \mathrm{m}^{-2} \mathrm{~s}^{-1}\right)$. Nodal explants from $25-27$ day old in vitro seedlings served as explants and for somatic embryogenesis green cotyledons were used as explants.

Culture media: Basal medium comprised MS basal salts, 3\% sucrose and $0.8 \%$ agar supplemented with different concentrations of auxins - IAA (0.05 - 0.1 $\mathrm{mg} / \mathrm{l})$, cytokinins - BAP $(0.5-3.0 \mathrm{mg} / \mathrm{l}), \mathrm{Kn}(0.5 \mathrm{mg} / \mathrm{l})$ before autoclaving. The $\mathrm{pH}$ of the media was adjusted to 5.8 before adding agar and was autoclaved at 15 psi at $121^{\circ} \mathrm{C}$ for $20 \mathrm{~min}$. Cultures were maintained at $24 \pm 2^{\circ} \mathrm{C}$ and $50-60 \%$ relative humidity $(\mathrm{RH})$ under $14 \mathrm{~h}$ photoperiod in a growth chamber. Subculturing was made periodically at 20 - 25 days interval to obtain adequate number of shoots. For root initiation the shoots were transferred to the rooting medium containing different levels of IAA.

Hardening and acclimation: Plantlets were washed thoroughly with running tap water and planted in pots containing various types of sterilized potting media (red soil and sand, $1: 1$ ), vermiculate + sand + sphagnum mass $(1: 1: 1)$, commercial media consisting of decomposed coir waste + perlite + compost $(1: 1$ $: 1)$, vermin-compost and red soil + sand (1:1:1). During hardening process, initially the plantlets were kept under shade-net located inside the $75 \%$ shade house for 10 days. After 10 days they were transferred to $75 \%$ of the time in the shade house and maintained there for two weeks. Thereafter, they were grown under field conditions. The data obtained from five replicates were statistically analyzed using DMRT.

Induction of somatic embryogenesis: After washing thrice with sterile distilled water the embryos were dissected out from the seeds and inoculated aseptically on MS containing $30 \mathrm{~g} / 1$ sucrose, gelled with $8 \mathrm{~g} / 1$ of agar and supplemented with coconut water (Table 3). The cultures were maintained at $24 \pm 2{ }^{\circ} \mathrm{C}$ in total darkness for $24 \mathrm{~h}$ and then transferred to a light regime of $14 \mathrm{~h}$ cool white florescent light (3000 lux). 


\section{Results and Discussion}

Nodal culture: Nodal explants collected from in vitro and field grown individuals produced a single shoot on basal MS within $10-12$ days (Plate 1$)$. The addition of BAP (1.5 mg/l), Kn (0.5 mg/l) and IAA (0.1 mg/l) induced a maximum of 30 - 40 shoots per explant within a period of 30 - 40 days (Table 1 and Plate 1 ). The other combinations of MS with BAP, Kn and IAA at 1.0, 0.5 and $0.1 \mathrm{mg} / 1$, respectively
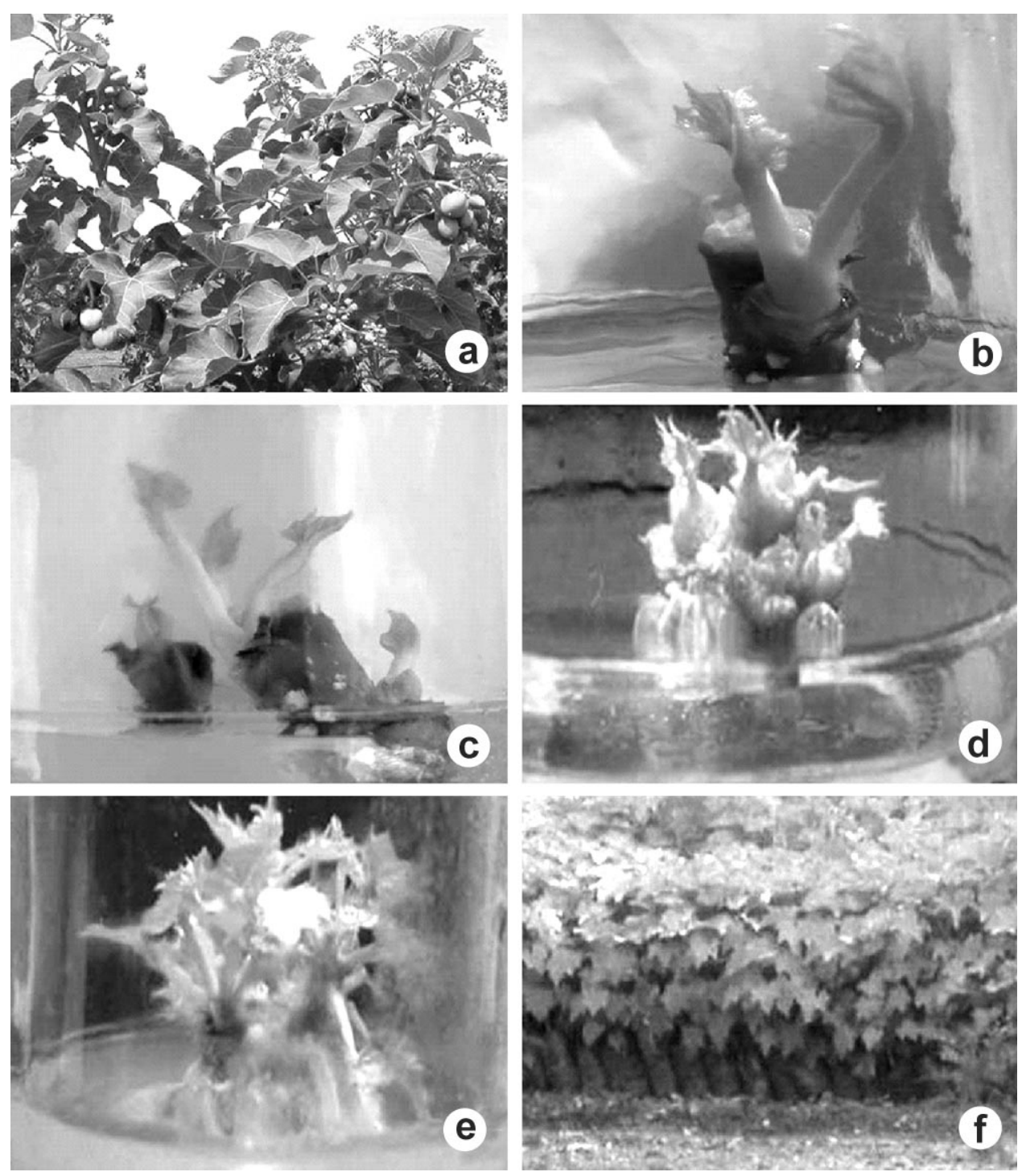

Plate 1. Different stages of in vitro propagation of Jatropha curcas on growth regulators supplemented MS. a. Mother plant; b-c. Shoot initiation on MS + BAP $(1.5 \mathrm{mg} / \mathrm{l})+\mathrm{Kn}$ $(0.5 \mathrm{mg} / \mathrm{l})+$ IAA $(0.1 \mathrm{mg} / \mathrm{l}) ; \mathrm{d}$. Multiple shoot formation on the same medium; e. Rooted plantlets. f. Hardened plants. 
were also effective but not at the previous combinations level. The in vitro differentiated shoots were cut into segments each with a single node and subcultured in MS supplemented with BAP, Kn and IAA for further multiplication. It is a common fact that cytokinin and auxins were found essential for shoot multiplication. The earlier studies report that several types of explants of $J$ curcas responded very positively to these hormones with respect to induction of callus, shoots, roots, somatic embryos (Sujatha and Mukta 1996, Jyoti-Sardana et al. 2000). In the present study for the first time nodes are used as explants and plantlets were established successfully within 10 weeks of culture by using cytokinins and auxins. In the present investigation a lower concentration of $\mathrm{Kn}$ and IAA and a slightly higher concentration of BAP proved to yield the best result with respect to shooting. The higher concentrations of auxins are generally inhibitory to morphogenesis; and substitution of these reagents with an appropriate auxin-cytokinin ratio is essential to obtain proper shoot- and root primordia.

Table 1. Effect of growth regulators -fortified MS on multiple shoots induction.

\begin{tabular}{lcccccc}
\hline $\begin{array}{l}\text { MS medium + } \\
\text { growth regulator } \\
(\mathrm{mg} / \mathrm{l})\end{array}$ & \multicolumn{3}{c}{ Shoot tip } & & Node & \\
\hline BAP + Kn + IAA & $\begin{array}{c}\text { Frequency } \\
(\%)\end{array}$ & $\begin{array}{c}\text { No } \\
\text { shoots } / \\
\text { explants }\end{array}$ & $\begin{array}{c}\text { Shoot } \\
\text { length } \\
(\mathrm{cm})\end{array}$ & $\begin{array}{c}\text { Frequency } \\
(\%)\end{array}$ & $\begin{array}{c}\text { No } \\
\text { shoots } / \\
\text { explants }\end{array}$ & $\begin{array}{c}\text { Shoot } \\
\text { length } \\
(\mathrm{cm})\end{array}$ \\
\hline $0.5+0.5+0.05$ & $60.0^{\mathrm{a}}$ & $20.0^{\mathrm{a}}$ & $1.5^{\mathrm{a}}$ & $65.0^{\mathrm{a}}$ & $22.0^{\mathrm{a}}$ & $1.6^{\mathrm{a}}$ \\
$1.0+0.5+0.05$ & $70.0^{\mathrm{b}}$ & $25.0^{\mathrm{b}}$ & $2.0^{\mathrm{a}-\mathrm{b}}$ & $69.0^{\mathrm{b}}$ & $24.0^{\mathrm{b}}$ & $2.1^{\mathrm{a}-\mathrm{b}}$ \\
$1.5+0.5+0.05$ & $75.0^{\mathrm{c}}$ & $27.0^{\mathrm{c}}$ & $3.3^{\mathrm{a}-\mathrm{c}}$ & $80.0^{\mathrm{c}}$ & $30.0^{\mathrm{c}}$ & $3.5^{\mathrm{a}-\mathrm{c}}$ \\
$2.0+0.5+0.05$ & $71.0^{\mathrm{d}, \mathrm{b}}$ & $18.0^{\mathrm{d}, \mathrm{b}}$ & $2.2^{\mathrm{a}-\mathrm{d}}$ & $73.0^{\mathrm{d}}$ & $19.0^{\mathrm{d}}$ & $2.3^{\mathrm{a}-\mathrm{d}}$ \\
$2.5+0.5+0.05$ & $62.0^{\mathrm{e}}$ & $15.0^{\mathrm{e}}$ & $1.5^{\mathrm{a}-\mathrm{e}}$ & $60.0^{\mathrm{e}}$ & $15.0^{\mathrm{e}}$ & $1.6^{\mathrm{a}-\mathrm{e}}$ \\
$3.0+0.5+0.05$ & $50.0^{\mathrm{f}}$ & $7.0^{\mathrm{f}}$ & $1.0^{\mathrm{a}-\mathrm{f}}$ & $53.0^{\mathrm{f}}$ & $8.0^{\mathrm{f}}$ & $1.5^{\mathrm{a}-\mathrm{f}}$ \\
$0.5+0.1+0.05$ & $80.0^{\mathrm{g}}$ & $31.0^{\mathrm{g}}$ & $2.3^{\mathrm{a}-\mathrm{g}}$ & $90.0^{\mathrm{g}}$ & $28.0^{\mathrm{g}}$ & $2.5^{\mathrm{a}-\mathrm{g}}$ \\
$1.0+1.0+0.05$ & $87.0^{\mathrm{h}}$ & $32.0^{\mathrm{g}-\mathrm{h}}$ & $3.0^{\mathrm{a}-\mathrm{h}}$ & $95.0^{\mathrm{h}}$ & $33.0^{\mathrm{h}}$ & $2.7^{\mathrm{a}-\mathrm{h}}$ \\
$1.5+0.1+0.05$ & $95.0^{\mathrm{I}}$ & $35.0^{\mathrm{I}}$ & $4.3^{\mathrm{I}, \mathrm{b}-}$ & $100.0^{\mathrm{I}}$ & $45.0^{\mathrm{I}}$ & $4.5^{\mathrm{I}, \mathrm{b}-\mathrm{c}, \mathrm{fgh}}$ \\
$2.0+0.1+0.05$ & $85.0^{\mathrm{c}, \text { fgh }}$ & $25.0^{\mathrm{j}, \mathrm{b}}$ & $3.2^{\mathrm{a}, \mathrm{c}-\mathrm{e}, \mathrm{f}-\mathrm{j}}$ & $92.0^{\mathrm{j}}$ & $30.0^{\mathrm{j}}$ & $3.7^{\mathrm{a}, \mathrm{c}-\mathrm{e}, \mathrm{f}-\mathrm{j}}$ \\
$2.5+0.1+0.05$ & $75.0^{\mathrm{k}, \mathrm{c}}$ & $12.0^{\mathrm{k}}$ & $2.0^{\mathrm{a}-\mathrm{k}}$ & $85.0^{\mathrm{k}}$ & $25.0^{\mathrm{k}}$ & $2.7^{\mathrm{a}-\mathrm{k}}$ \\
$3.0+0.1+0.05$ & $70.0^{\mathrm{l}, \mathrm{b}, \mathrm{d}}$ & $5.0^{\mathrm{l}}$ & $1.5^{\mathrm{a}-\mathrm{l}}$ & $80.0^{\mathrm{Ic}}$ & $15.0^{\mathrm{lc}}$ & $2.0^{\mathrm{a}-\mathrm{l}}$ \\
\hline
\end{tabular}

Values followed by same letters do not differ significantly at 5\% level by DMRT.

For rooting of microshoots, a medium with full strength MS was used. The well-developed microshoots were cut and placed vertically on MS fortified with various concentrations of auxins viz., IAA, and IBA at 5 different concentrations such as 0.5, 1.0, 1.5, 2.0 and $2.5 \mathrm{mg} / 1$ (Table 2). All the inoculated shoots, 
produced roots on MS containing IAA (1.0 mg/l) within 6 - 7 days. However, a higher concentration of IAA $(1.5 \mathrm{mg} / \mathrm{l})$ in the MS medium reduced the number of roots. MS supplemented with IBA was found to be unsuitable for rooting because of the formation of callus at the basal cut end of the shoots. Similar findings have also been reported by Sujatha and Mukta (1996). Among two auxins, IAA $(1.0 \mathrm{mg} / \mathrm{l})$ was found to be a more suitable hormone for root induction (Table 2). However, in the case of shoot tip culture of J. curcas, IBA (0.5 - $5.0 \mathrm{mg} / \mathrm{l}$ ) incorporated singly in MS was found suitable for root induction (Rojore and Batra 2005).

Table 2. Effect of growth regulators -fortified MS on root induction.

\begin{tabular}{lcccc}
\hline $\begin{array}{l}\text { MS medium }+ \\
\text { Growth regulators } \\
(\mathrm{mg} / \mathrm{l})\end{array}$ & $\begin{array}{c}\text { No of } \\
\text { days for } \\
\text { rooting }\end{array}$ & $\begin{array}{c}\text { Rooting } \\
\text { frequency }\end{array}$ & $\begin{array}{c}\text { Base } \\
\text { callusing } \\
\text { frequency }\end{array}$ & $\begin{array}{c}\text { Root length/ } \\
\text { explants } \\
(\mathrm{cm})\end{array}$ \\
\hline IAA & $10-12^{\mathrm{a}}$ & $42.0^{\mathrm{a}}$ & - & $2.3^{\mathrm{a}}$ \\
0.5 & $6-7^{\mathrm{b}}$ & $97.0^{\mathrm{b}}$ & - & $5.5^{\mathrm{b}}$ \\
1.0 & $6-7 \mathrm{cb}$ & $75.0^{\mathrm{c}}$ & - & $3.9 \mathrm{c}$ \\
1.5 & $9-10^{\mathrm{d}}$ & $40.0^{\mathrm{d}}$ & - & $3.2^{\mathrm{dc}}$ \\
2.0 & $10-14^{\mathrm{e}}$ & $32.0^{\mathrm{e}}$ & - & $2.9^{\mathrm{ed}}$ \\
2.5 & & & & $2.0^{\mathrm{a}}$ \\
IBA & $8-9 \mathrm{a}$ & $16.0^{\mathrm{a}}$ & - & $4.0^{\mathrm{b}}$ \\
0.5 & $10-12^{\mathrm{b}}$ & $17.0^{\mathrm{b}}$ & + & $3.3^{\mathrm{c}}$ \\
1.0 & $11-12^{\mathrm{cb}}$ & $14.0^{\mathrm{c}}$ & ++ & $2.8^{\mathrm{dc}}$ \\
1.5 & $12-14^{\mathrm{d}}$ & $28.0^{\mathrm{d}}$ & ++ & $2.7^{\mathrm{c}-\mathrm{e}}$ \\
2.0 & $10-13^{\mathrm{ec}}$ & $33.0^{\mathrm{e}}$ & +++ & + \\
2.5 & & & + & \\
\hline
\end{tabular}

Means followed by a common letter are not significantly different at the $5 \%$ level by DMRT.

The well developed healthy in vitro rooted plantlets were washed thoroughly in running tap water and hardened with different potting media. In this study, a maximum survival rate of $85 \%$ was obtained in the potting medium containing decomposed coir waste + perlite + compost (hardening media) followed by vermin-compost (70\%). Plantlets derived from somatic embryos did neither go through the hardening process nor were tested in different potting media; presumably their performance will not be different from those obtained from organogenesis.

Somatic embryogenesis: The green cotyledons excised from seeds served as explants for somatic embryogenesis. The cotyledonary explants were grown in full and half strength of MS augmented with coconut water (CW). Some seeds were grown in MS containing different concentrations of BAP (Table 3). In MS containing BAP (2 mg/l), small globular glossy somatic embryos started to 
appear from the upper surface of the cotyledon within 7 - 8 days. These structures further developed into dark green colored embryos. The data presented in Table 4 showed that the MS supplemented with BAP at $2.0 \mathrm{mg} / 1$ was found to be most suitable for the initiation and development of somatic embryos (Table 3, Plate 2).

It is generally known that auxin in high concentrations induces somatic embryos effectively. The results on direct somatic embryogenesis have shown that BAP is essential for inducing somatic embryogenesis from cotyledonary explants of J. curcas. However, Ramasamy et al. 2005 reported that auxin or auxins in combination with cytokinin greatly influences the frequency and also has a significant impact on the maturation of somatic embryos. Kumari and Jaiwal (1998) found the requirement of cytokinin in addition to auxin essential to induce somatic embryogenesis in Terminalia arjuna. Similar observation was made for the species Psoralea corylifolia (Sahrawat and Chand 2001). Unlike the above two reports, we also obtained somatic embryogenesis with cytokinin only. Similar to the present observation, there are reports that BAP alone, when added to the basal medium, induced direct somatic embryogenesis. Examples are: Hipperstrum hybridum (Mujib et al. 1998) and Sequoia sempervirens (Liu et al. 2006).

Table 3. Effects of media on embryo germination.

\begin{tabular}{lccccc}
\hline \multirow{2}{*}{ Medium } & \multicolumn{5}{c}{ Time taken for (in days) } \\
\cline { 2 - 6 } & $\begin{array}{c}\text { Greening of } \\
\text { the embryo }\end{array}$ & $\begin{array}{c}\text { Cotyledonary } \\
\text { leaf }\end{array}$ & First leaf & Second leaf & Third leaf \\
\hline MS & $5-7$ & $8-10$ & $15-20$ & - & - \\
MS + CW & $1-2$ & $2-3$ & $4-5$ & $5-6$ & $6-8$ \\
$1 / 2$ MS & $8-10$ & $10-11$ & $14-16$ & - & - \\
$1 / 2$ MS + CW & $5-9$ & $10-12$ & $12-14$ & $15-17$ & $20-$ \\
& & & & & 22 \\
MS + BAP & & & & & \\
$(\mathrm{mg} / 1)$ & $6-8$ & $6-8$ & $15-20$ & - & - \\
0.5 & $6-8$ & $6-8$ & $16-20$ & - & - \\
1.0 & $6-8$ & $8-10$ & $18-20$ & - & - \\
1.5 & $8-10$ & - & - & - & - \\
2.0 & & & & & \\
\hline
\end{tabular}

Means followed by a common letter are not significantly different at the $5 \%$ level by DMRT.

Histology of direct somatic embryogenesis: The somatic embryos were developed after two weeks of inoculation (Plate 2a-b) following the development of several layers of meristematic cells (Plate 2c). Developing embryos were composed of small embryonic cells and they were characterized by densely stained cytoplasm (Plate $2 \mathrm{~d}$ ). The progression stage in shoot initiation is clearly 
shown in Plate 2e-f. To our knowledge this is the first report describing the formation of direct somatic embryogenesis in J. curcas in BAP-supplemented MS medium. Further work on plantlet formation from somatic embryos and hardening is in progress. Direct embryogenesis observed in J. curcas has a great potential for its application in mass propagation. In addition, repetitive embryogenesis can also be used for synthetic seed production and genetic transformation (Bhojwani and Razdan 1996).
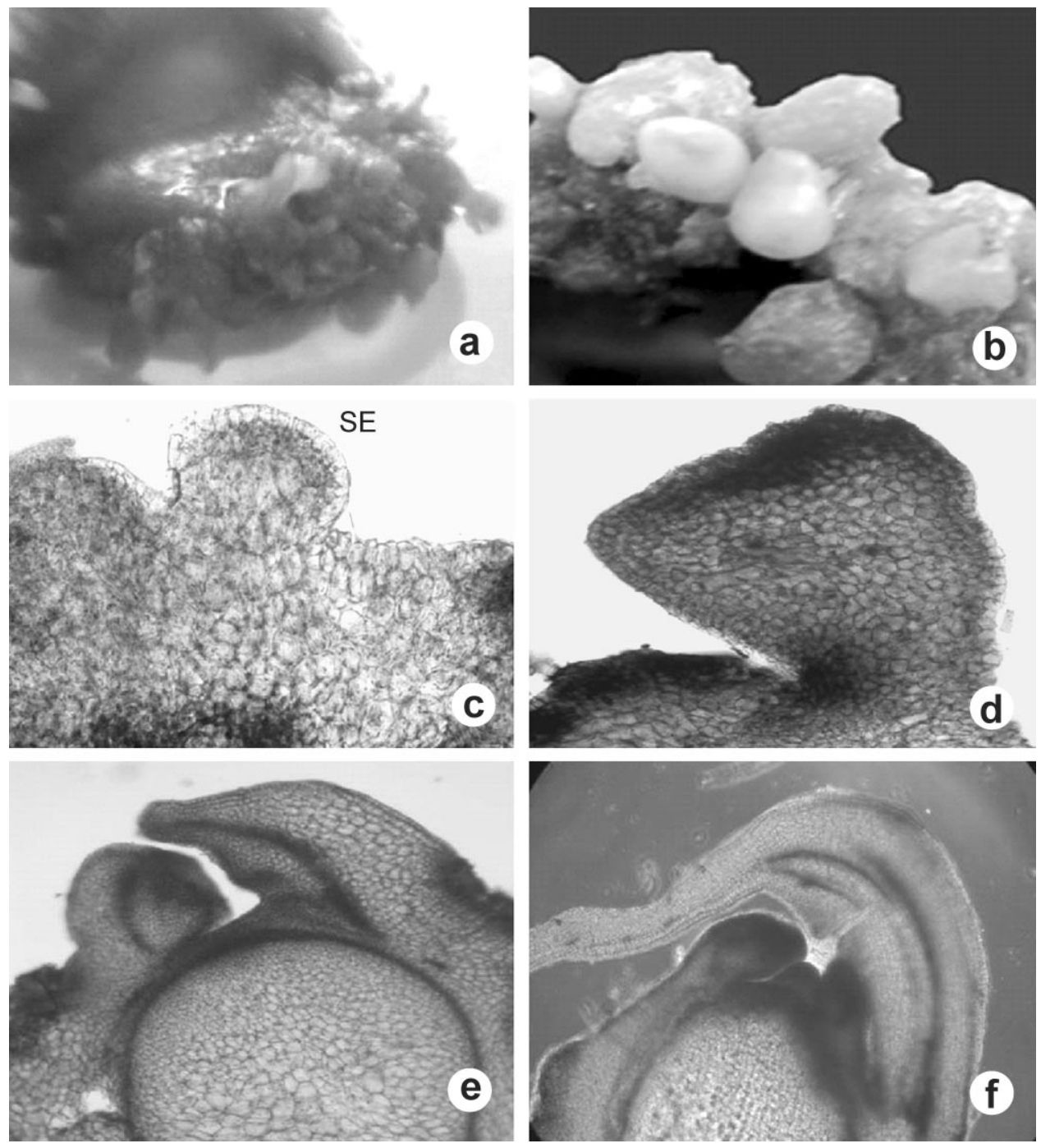

Plate 2. Somatic embryo formation and histology of direct somatic embryogenesis at various developmental stages of J. curcas. a-b. Somatic embryos formed from cotyledonary leaf explants after 8 days of culture. c. A somatic embryo (SE) containing small embryonic cells developed from the epidermal layer. $d$. The dense cytoplasm in the bulged embryo. e-f. Initiation of shoots from the cotyledonary embryos. 
It is concluded that for effective micropropagation MS medium needs to be standardized in the following manner, moderate concentration of BAP (1.5 $\mathrm{mg} / \mathrm{l}), \mathrm{KN}(0.5 \mathrm{mg} / \mathrm{l})$ and IAA $(0.1 \mathrm{mg} / \mathrm{l})$ for successful shoot formation from nodal explants. The same concentration of growth hormone supplemented in MS, used for shoot induction is also suitable for multiple shoot induction during subculturing. IAA at the concentration of $1 \mathrm{mg} / 1 \mathrm{in}$ MS medium enhances root initiation at a higher level. The hardening medium comprising decomposed coir waste, perlite and compost in the ratio of $1: 1: 1$ enhanced the survivability rate of plantlets at $80 \%$. Hence, the protocol developed in the present study may prove to be suitable for massive in vitro plantlet production of J. curcas. Given suitable cultural and environmental conditions the protocol may be tried in subtropical regions of the world.

Table 4. Effect of BAP-fortified MS medium on somatic embryogenesis.

\begin{tabular}{cccc}
\hline $\begin{array}{c}\text { MS + BPA } \\
(\mathrm{mg} / \mathrm{l})\end{array}$ & $\begin{array}{c}\text { Time taken for } \\
\text { somatic embryo } \\
\text { formation (days) }\end{array}$ & $\begin{array}{c}\text { Explants forming } \\
\text { somatic embryo } \\
(\%)\end{array}$ & $\begin{array}{c}\text { Number of } \\
\text { S.E./explant }\end{array}$ \\
\hline 0.5 & - & - & - \\
1.0 & - & - & - \\
1.5 & 20 & 20 & 5 \\
2.0 & 8 & 90 & 40 \\
2.5 & 15 & 35 & 9 \\
3.0 & - & - & - \\
\hline
\end{tabular}

Somatic embryogenesis tried as an alternative and efficient method for plant propagation yielded promising results from two angles, first the regenerants being derived from single embryonic cell were true to type and second a large number of plantlets were produced within a short period of time (Ammirato 1983). Many workers have emphasized that the somatic embryogenesis is a preferred method for rapid in vitro multiplication of plants (Robert et al. 1995, Mohan et al. 2000) and also for production of artificial seeds (Ahuja et al. 1989, Maruyama et al. 1997) and Agrobacterium-mediated transformation and regeneration of transgenic plants (McGranahan et al. 1989).

\section{References}

Ahuja DS, Mathur J, Lala N, Mathur AK and Kukreja AK (1989) Towards developing artificial seeds by shoot bud encapsulation in Tissue culture and biotechnology of medicinal and aromatic plants. A.K Kukreja et al. (Ed.), pp. 22-28.

Ammirato PV (1983) Embryogenesis, in Hand book of plant cell cultures. Vol. I. D.A. Evans et al. (Ed.), 82-123. 
Banerji R, Chowdhury AR, Misra G, Sudarsanam G, Verma SC and Srivastava GS (1985) Jatropha seed oils for energy. Biomass 8: 277-282.

Bhojwani SS and Razdan M.K (1996) Plant Tissue Culture: Theory and Practice (Elsevier, Amsterdam) 125-166.

Dehgan B and Webster G.L (1979) Morphology and intrageneric relationships of the genus Jatropha (Euphorbiaceae). University Calif. Publications in Botany 74.

Godbole SR, Pandse GS and Badekar VS (1966) Glossary of Vegetable Drugs in Vegbhatt (Published by Dr. G.S Pandse for IDRA, Poona, India).

Heller J (1996) Physic nut. Jatropha curcas L. promoting the conservation and use of underutilized and neglected crops. 1. Institute of Plant Genetic and Crop Plant Research, Gatersleben/International Plant Genetic Resource Institute, Rome.

Jyoti-Sardana, Amla B and Deewan J (2000) An expeditious method for regeneration of somatic embryos in J. curcas L. Phytomorphology, 50 (384): 239-242.

Kumari N and Jaiwal V S (1998) Induction of somatic embryogenesis and plant regeneration from leaf callus of Terminalia arjuna Bedd., Curr Sci 75: 1052-1055.

Larkin PJ and Scowcroft WR (1981) Somoclonal variation- a novel source of variability from cell cultures for plant environment. Theor. Appl. Genet. 60: 197-214.

Liu C, Xia X Yin W Hung L and Zhou J (2006) Shoot regeneration and somatic embryogenesis from needles of redwood (Sequoia sempervirens (D. Don.) Endl.). Plant Cell Rep. 25: 621-628.

Martin G and Mayeux A (1985) Curcas oil (Jatropha curcas. L.): a possible fuel. Agric. Trop. 9: 73-75.

Maruyama E, Kinoshita I, Ishii K, Ohba K and Saito (1997) A germplasm conservation of the tropical trees, Cedrela odorata L., Guazuma crinita Mort. and Jacaranda mimosaefolia D. Don by shoot tip encapsulation in calcium alginate and storage at $12-25^{\circ} \mathrm{C}$. Plant Cell Rep. 16: 393-396.

Mascarenhas AF, Gupta PK, Kulkarni VM, Mehta V, Iyer RS, Khuspe SS and Jaganthan V (1981) In Proc. COSTED Symposium on Tissue Culture of Economically important plant, Singapore 175.

Mascarenhas AF and Muralidharan (1989) Tissue culture of forest trees in India. Curr. Sci. 58. (1) 606-613.

McGranahan GH, Leslie CA, Urasta SL Martin LA and Dandekar AM (1989) Agrobacterium- mediated transformation of walnut somatic embryos and regeneration of transgenic plants. Biotechnology 6: 800-804.

Mohan JSS, Vijayakumar V, Aparna V and Vaidya RP (2000) Somatic embryogenesis and plant regeneration in Tribulus terrestis L. Phytomorphology 50: 307-311.

Muhlbauer W, Esper A, Stumpf E and Baumann R (1998) Workshop Report - Rural energy, equity and employment: Role of Jatropha curcas. The Rockefeller Foundation, Scientific Centre (SIRDC). Zimbabwe; May, 13-15.

Mujib A, Bandyopadhyay S, Jana BK and Ghosh PD (1998) Direct somatic embryogenesis and in vitro plant regeneration in Hippeastrum hybridum, Plant Tissue Cult. 8(1):19-25.

Ramasamy N, Ugandhar T, Praveen M, Venkataiah P, Rambabu M, Upender $\mathbf{M}$ and Subhash K (2005) Somatic embryogenesis and plantlet regeneration from cotyledons and leaf explants of Solanum surattense. Indian J. Biotech. 4: 414-418. 
Robert AV, Yokaya K, Walker S and Mottley J (1995) Somatic embryogenesis in woody plants Vol. 2 (edited by S. Jain et al. The Netherlands, pp. 277-280.

Rojore S and Batra A (2005) Efficient plant regeneration via shoot tip explants in J. curcas L. J. Plant Biochemistry and Biotechnology 14: 73-75.

Roy S (1998) Bio-fuel production from Jatropha curcas. In: Kopetz, H., Weber, T., Palz, W., Chartier, P and Ferrero, PL (eds.). Biomass for Energy \& Industry, Proceeding of International Conference, CARMEN, Rimpar, Germany, pp. 613-615.

Roy S and Kumar A (1990) Prospects of wood energy production semiarid arid regions of Rajasthan. In: Grassi G, Gosses G and dos Santos G (Eds.). Biomass for energy and Industry. Elsevier Applied Sci. Publications, London and New York, 2, 2.1153-2.1156.

Roy S (1990) Effect of various factors on growth and productivity of Jatropha curcas, a hydrocarbon yielding plant. In: Grassi G, Gosses G and dos Santos G (Eds.). Biomass for Energy and Industry Vol. I. Elsevier applied Sci. Publication, London and New York; pp. 1484-1488.

Roy S (1995) Clonal propagation of an endangered tree of high economic value: Sterculia urens. Int. J. Mentel 12: 32-33.

Sahrawat AK and Chand S (2001) Continuous somatic embryogenesis and regeneration from hypostyle segments of Psoralea corylifolia Linn: An endangered and medicinally important Fabaceae plant. Curr. Sci. 81:1328-1331.

Sakaguchi S, Sukarin W and Kalpatcharanurar W (1987) Mutation breeding of sacudam (Jatropha curcas. L. physic nut in English). In Sakaguchi, S.; Somabhi, M. (Eds). Exploitation of promising crops in Northeast Thailand (pp. 3-20). Sririphan offset Publication, Khonkaen, Thailand.

Spera MRN, Pasqual M, Maciel ALR and Salvador ED (1997) Effect of different concentration of Knetin and 2-4D on the in vitro cultivation of Jatropha podagrica Hook'roots. Ciencia e Agrotecnologia 21: 386-389.

Sujatha M and Dhingra M (1993) Rapid plant regeneration from various explants of $J$. integerrima. Plant Cell Tissue and Organ Cult. (Netherlands). 35: 293-296.

Sujatha M and Mukta N (1996) Morphogenesis and plant regeneration from tissue culture of Jatropha curcas. Plant Cell, Tissue and Organ Culture 44: 135-141

Sujatha M, Makkar HPS and Becker K (2005) Shoot bud proliferation from axillary nodes and leaf section of nontoxic J. curcas L. Plant growth regulation 47: 83-90.

Sujatha M and Prabakaran AJ (2003) New ornamental Jatropha hybrids through interspecific hybridization. Genetic resource and Crop Evo. 50: 75-82.

Takeda Y (1982) Development study on Jatropha curcas (Sabu dum) oil as a substitute for diesel engine oil in Thailand. J. Agric Assoc. China 120:1-8. 